\title{
Binding Studies of a New Water-Soluble Iron(III) Schiff Base Complex to DNA Using Multispectroscopic Methods
}

\author{
Nahid Shahabadi, Zeinab Ghasemian, and Saba Hadidi \\ Department of Inorganic Chemistry, Faculty of Chemistry, Razi University, Kermanshah 74155, Iran \\ Correspondence should be addressed to Nahid Shahabadi, nahidshahabadi@yahoo.com \\ Received 4 April 2012; Accepted 11 June 2012 \\ Academic Editor: Giovanni Natile
}

Copyright (C) 2012 Nahid Shahabadi et al. This is an open access article distributed under the Creative Commons Attribution License, which permits unrestricted use, distribution, and reproduction in any medium, provided the original work is properly cited.

A novel iron(III) complex $[\mathrm{Fe}(\mathrm{SF})]\left(\mathrm{ClO}_{4}\right)_{3} \cdot 2 \mathrm{H}_{2} \mathrm{O}$; in which $\mathrm{SF}=\mathrm{N}, \mathrm{N}_{0}$-bis $\{5$-[(triphenylphosphonium chloride)-methyl] salicylidene $\}$-o-phenylenediamine) has been synthesized and characterized using different physicochemical methods. The binding of this complex with calf thymus (CT) DNA was investigated by circular dichroism, absorption studies, emission spectroscopy, voltammetric studies, and viscosity measurements. The results showed that this complex can bind to DNA via external and groove binding modes.

\section{Introduction}

Schiff bases, characterized by the azomethine group $(-\mathrm{RC}=$ $\mathrm{N}-$ ), form a significant class of compounds in medicinal and pharmaceutical chemistry and are known to have biological applications due to their antibacterial [1-6], antifungal [3$6]$, and antitumor [7, 8] activity. Schiff base ligands are considered "privileged ligands" because they are easily prepared by the condensation between aldehydes and imines. The incorporation of transition metals into these compounds leads to the enhancement of their biological activities and decrease in the cytotoxicity of both metal ion and Schiff base ligand [9-11]. Schiff bases with donors ( $N, O, S$, etc.) have structural similarities with neutral biological systems and due to presence of imine group are utilized in elucidating the mechanism of transformation of racemization reaction in biological system [12-14]. Those play an important role in inorganic chemistry as they easily form stable complexes with most transition metal ions.

The structural diversity of transition metal complexes of Schiff base ligands and the structure function relationships of the resulting complexes have been the focus of extensive research in recent years [15-21]. Metal complexes have been widely applied in clinics for centuries, although their molecular mechanism has not yet been entirely understood [22, 23]. The binding and reaction of metal complexes with DNA have been the subjects of intense investigation in relation to the development of new reagents for biotechnology and medicine [24-30]. To understand such functions and to design new DNA-binding metal complexes, investigations of the DNA-binding structures of the complexes are inevitably necessary. Investigations on the interaction between transition metal complexes and DNA has attracted many interests due to their importance in cancer therapy and molecular biology [31-39].

It is well known that some drugs have higher activity when administered as metal complexes than as free ligands [40]. Among them less explored iron-based Schiff base complexes possess many advantages over traditional catalyst due to iron's copious, nontoxic, and inexpensive nature [41]. In this context, we studied the interaction of a new iron(III) complex of a Schiff base ligand (Figure 1) with calf thymus DNA using physicochemical methods.

\section{Experimental}

2.1. Materials. O-phenylenediamine, salicylaldehyde, p-formaldehyde, triphenylphosphine, absolute ethanol, iron nitrate nona hydrate, diethyl ether, dichloromethane, ethylacetate, $\mathrm{NaClO}_{4} \cdot \mathrm{H}_{2} \mathrm{O}$, EDTA, Tris- $\mathrm{HCl}, \mathrm{NaOH}$, potassium 


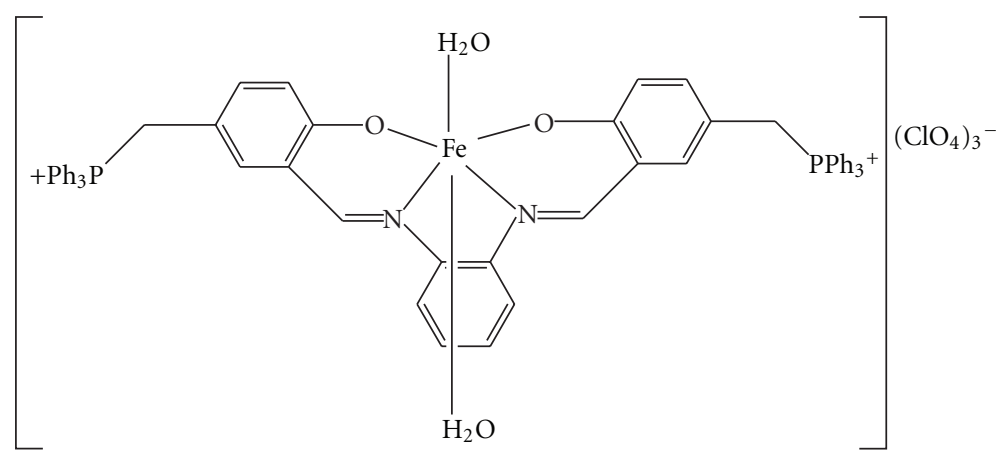

FIgURe 1: The molecular structure of iron(III) complex.

acetate, and chloroform, were purchased from Merck. Doubly distilled deionized water was used throughout. Highly polymerized CT-DNA and Tris-HCl buffer were purchased from Sigma.

Experiments were carried out in Tris- $\mathrm{HCl}$ buffer at $\mathrm{pH}$ 7.2. Solutions of CT-DNA gave a UV absorbance ratio ( 260 over $280 \mathrm{~nm}$ ) of more than 1.8 , indicating that the DNA was sufficiently free of protein. The stock solution of CT-DNA was prepared by dissolving approximately $1-2 \mathrm{mg}$ of CTDNA fibers in $2 \mathrm{~mL}$ Tris- $\mathrm{HCl}(10 \mathrm{mM})$ by shaking gently and stored for $24 \mathrm{~h}$ at $4^{\circ} \mathrm{C}$. The DNA concentration (monomer units) of the stock solution $\left(1 \times 10^{-2} \mathrm{M}\right.$ per nucleotide $)$ was determined by UV spectrophotometry in properly diluted samples using a molar absorption coefficient of $6600 \mathrm{M}^{-1} \mathrm{~cm}^{-1}$ at $258 \mathrm{~nm}$. DNA solutions were used after no more than 4 days.

2.2. Instrumentation. The elemental analysis was performed using a Heraeus CHN elemental analyzer. Absorbance spectra were recorded using an HP spectrophotometer (Agilent 8453) equipped with a thermostated bath (Huber polysat $\mathrm{cc1}$ ). Absorption titration experiments were conducted by keeping the concentration of complex constant $\left(5 \times 10^{-5} \mathrm{M}\right)$ while varying the DNA concentration from 0 to $2.5 \times 10^{-4} \mathrm{M}$ $(\mathrm{ri}=[\mathrm{DNA}] /[$ complex $]=0.0,0.15,0.35,0.4,0.55,0.65$, and $0.7)$. Absorbance values were recorded after each successive addition of DNA solution, followed by an equilibration period. CD measurements were recorded on a JASCO (J-810) spectropolarimeter, keeping the concentration of DNA constant $\left(8 \times 10^{-5} \mathrm{M}\right)$ while varying the complex concentration $(\mathrm{ri}=[$ complex $] /[\mathrm{DNA}]=\mathrm{ri}=0,0.2,0.4$, $0.6,0.8$, and 1$)$. Viscosity measurements were made using a viscosimeter (SCHOT AVS 450) maintained at $25.0 \pm 0.5^{\circ} \mathrm{C}$ using a constant temperature bath. The DNA concentration was fixed at $5 \times 10^{-5} \mathrm{M}$, and flow time was measured with a digital stopwatch. The mean values of three measurements were used to evaluate the viscosity $\eta$ of the samples. The values for relative specific viscosity $\left(\eta / \eta_{0}\right)^{1 / 3}$, where $\eta_{0}$ and $\eta$ are the specific viscosity contributions of DNA in the absence $\left(\eta_{0}\right)$ and in the presence of the complex $(\eta)$, were plotted against $\mathrm{ri}(\mathrm{ri}=[\mathrm{DNA}] /[$ complex $]=0.0$, $0.2,0.4,0.6,0.8$, and 1.0). All fluorescence measurements were carried out with a JASCO spectrofluorimeter (FP6200) by keeping the concentration of complex constant while varying the DNA concentration from 0 to $5 \times 10^{-5} \mathrm{M}$ $(\mathrm{ri}=[\mathrm{DNA}] /[$ complex $]=0.0,0.08,0.16,0.32,0.4,0.48,0.55$, $0.62,1$, and 1.1$)$ at three different temperatures $(298,310$, and $288 \mathrm{~K})$. The cyclic voltammetric (CV) measurements were performed using an $\mu$-AUTOLAB model (PG STAT $\mathrm{C})$, with a three-electrode system: a $0.10 \mathrm{~cm}$ diameter Glassy carbon (GC) disc as working electrode, an $\mathrm{Ag} / \mathrm{AgCl}$ electrode as reference electrode, and a Pt wire as counter electrode. Electrochemical experiments were carried out in a $25 \mathrm{~mL}$ voltammetric cell at room temperature. All potentials are referred to the $\mathrm{Ag} / \mathrm{AgCl}$ reference. Their surfaces were freshly polished with $0.05 \mathrm{~mm}$ alumina prior to each experiment and were rinsed using double distilled water between each polishing step. The supporting electrolyte was $0.05 \mathrm{M}$ of Tris- $\mathrm{HCl}$ buffer solution ( $\mathrm{pH}$ 7.4) which was prepared with double distilled water. The current-potential curves and experimental data were recorded on software NOVA 1.6.

2.3. Synthesis of the Iron(III) Schiff Base Complex. To a vigorously stirred solution $(10 \mathrm{~mL})$ of 3-formyl-4 hydroxybenzyltriphenyl phosphonium chloride $(0.12 \mathrm{~g}, 2 \mathrm{mmol})$ was first added $\mathrm{Fe}\left(\mathrm{NO}_{3}\right)_{3} \cdot 9 \mathrm{H}_{2} \mathrm{O}(0.136 \mathrm{~g}, 2 \mathrm{mmol})$ dissolved in water $(10 \mathrm{~mL})$ and then $\mathrm{Et}_{3} \mathrm{~N}$ (pH 7.5-8). A few minutes later, an ethanolic solution $(2 \mathrm{~mL})$ of o-phenylenediamine $(0.015 \mathrm{~g}$, $1 \mathrm{mmol}$ ) was added drop wise. The solution turned to dark brown and the mixture was vigorously stirred and refluxed for $3 \mathrm{~h}$ under an argon atmosphere. After that, $\mathrm{NaClO}_{4} \cdot \mathrm{H}_{2} \mathrm{O}$ $(2 \mathrm{mmol})$ was dissolved in a minimum amount of water $(5 \mathrm{~mL})$ and added to the reaction mixture. The resulting brown powder precipitate was collected by filtration, washed with cold ethanol and ether, and dried in air. The complex was dissolved in $\mathrm{CH}_{2} \mathrm{Cl}_{2}(6 \mathrm{~mL})$, Ethylacetate $(3 \mathrm{~mL})$ was added and the resulting solution was allowed to evaporate slowly at room temperature. The solid product was filtered off and washed with ethyl acetate and ether yielding the iron complex as a brown powder.

\section{Results and Discussion}

3.1. Synthesis and Characterization of Iron(III) Complex. The iron(III) complex of SF ligand $\left(\mathrm{SF}=\mathrm{N}, \mathrm{N}_{0}\right.$-bis $\{5$ [(triphenylphosphonium chloride)-methyl] salicylidene $\}$ o-phenylenediamine) synthesized by mixing 3-formyl4 hydroxybenzyl-triphenyl phosphonium chloride, Fe(III) 
nitrate and o-phenylenediamine in high yield. FT-IR spectrum of the complex was recorded in $\mathrm{KBr}$ pellets from 4000 to $400 \mathrm{~cm}^{-1}$. The FT-IR spectrum of the Schiff base was characterized by the appearance of a band at $3424 \mathrm{~cm}^{-1}$ due to the $(\mathrm{OH})$ group [42]. In the FT-IR spectrum of the iron(III) complex, the absence of this band indicates deprotonation of the donor and involvement oxygen in bonding with the metal atom. However, the strong band at ca. $1627 \mathrm{~cm}^{-1}$ assigned to $(\mathrm{CN})$ of the Schiff base ligand [43] which shifts approximately $16 \mathrm{~cm}^{-1}$ to the lower wave numbers upon coordination to metal [42]. Since the iron(III) is paramagnetic in nature, its NMR spectrum could not be obtained. Elemental analysis also confirms the synthesis of the complex. $\mathrm{FeC}_{58} \mathrm{H}_{52} \mathrm{~N}_{2} \mathrm{P}_{2} \mathrm{O}_{16} \mathrm{Cl}_{3}$ anal. calc.: C, 55.39; $\mathrm{H}$, 4.13; N, 2.22. Found: C, 55.21; H, 4.30; N, 2.45.

The electronic spectrum of the complex shows the band at $260 \mathrm{~nm}$ is attributable to intramolecular $\pi \rightarrow \pi^{*}$ transition. Another band at $340 \mathrm{~nm}$ could be attributed to metal to ligand charge transfer. The other weaker bands are attributed to $d \rightarrow d$ transitions of metal center. Molar conductance of the complex in DMF is $289 \Omega^{-1} \mathrm{~cm}^{2} \mathrm{~mol}^{-1}$ that is indicative of $3: 1$ electrolytic nature of the complex. Conclusive evidence of the bonding was also shown by the observation that new bands in the FT-IR spectra of the metal complex appearing in the low frequency region at $420-518 \mathrm{~cm}^{-1}$ characteristic to $-(\mathrm{M}-\mathrm{O})$ and $-(\mathrm{M}-\mathrm{N})$ stretching vibrations respectively that were not observed in the spectrum of free ligand.

3.2. Viscosity Measurements. Hydrodynamic methods that are sensitive to length are regarded as one of the least ambiguous and most critical tests of a binding mode in solution in the absence of crystallographic structural data. Intercalating agents are expected to elongate the double helix to accommodate the ligands in between the base leading to an increase in the viscosity of DNA. In contrast, complex that bind exclusively in the DNA grooves by partial and/or nonclassical intercalation, under the same conditions, typically cause less pronounced (positive or negative) or no change in DNA solution viscosity [44]. The values of $\left(\eta / \eta_{0}\right)^{1 / 3}$ were plotted against [complex]/[DNA] (Figure 2). With the increase in the amount of the complex, the relative viscosity of DNA increases steadily which is consistent with DNA groove binding which is also known to enhance DNA viscosity [42].

As intercalation causes a significant increase in viscosity of DNA solutions due to lengthening of the DNA helix as base pairs are separated to accommodate the aromatic chromophore of the bound molecule, it is tempting to ascribe the observed increase in viscosity to intercalative interaction of the complex. However, the effective intercalation of the phenyl rings of SF in iron complex is discouraged by several steric factors. This type of steric clash has been also suggested for the binding of $\left[\mathrm{Cu}(\mathrm{phen})_{2}\right]^{+}$ and $\left[\mathrm{Ru}(\mathrm{phen})_{3}\right]^{2+}$ complexes, where intercalation of a phen ligand is inhibited by steric interactions involving the other phen ligands with DNA surface. Therefore, it is obvious that the complex prefers to engage in DNA surface binding with

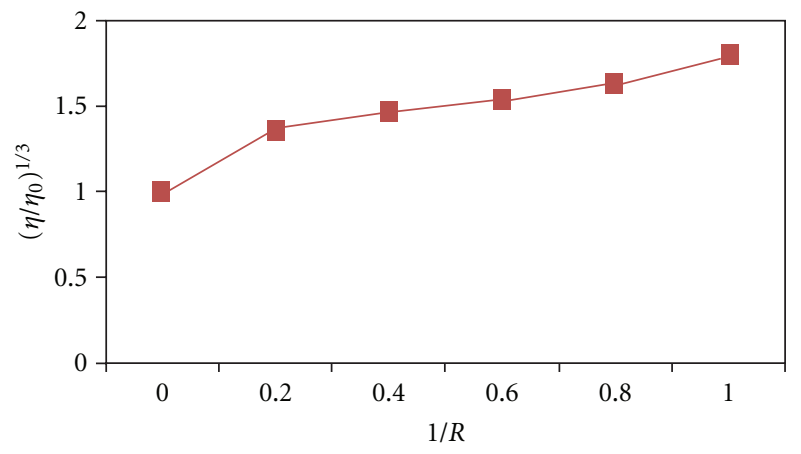

$R=$ complex $/ \mathrm{DNA}$

Figure 2: Effect of increasing amounts of iron complex on the viscosity of calf thymus DNA $\left(5 \times 10^{-5} \mathrm{M}\right)$ in $10 \mathrm{mM}$ Tris $\mathrm{HCl}$ buffer ( $\mathrm{ri}=0.2,0.4,0.6,0.8$, and 1$)$.

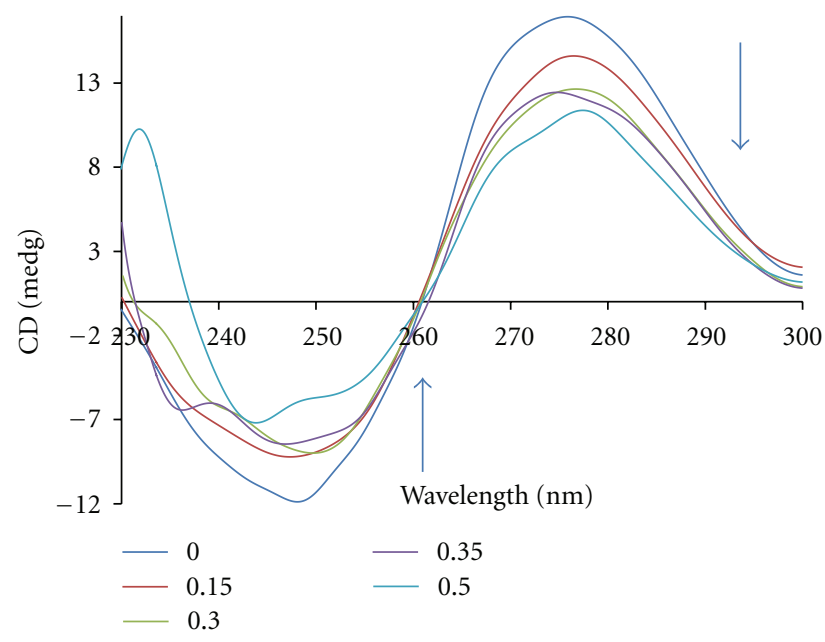

Figure 3

its large size affecting an increase in DNA viscosity, rather than in intercalative DNA interaction. The slow increase in viscosity is an indication of groove binding $[45,46]$.

3.3. CD Spectral Studies. Circular dichroic spectral techniques give us useful information on how the conformation of DNA is influenced by the binding of the metal complex to DNA. The observed CD spectrum of calf-thymus DNA consists of a positive band at $277 \mathrm{~nm}$ due to base stacking and a negative band at $245 \mathrm{~nm}$ due to helicity, which is characteristic of DNA in the right-handed B form. While groove binding and electrostatic interaction of small molecules with DNA show little or no perturbations on the base stacking and helicity bands, intercalation enhances the intensities of both the bands, stabilizing the right-handed $\mathrm{B}$ conformation of CT-DNA. The interaction between the complex and CTDNA was studied by CD spectroscopy (Figure 3 ).

In this case, the intensities of both the negative and positive bands decrease significantly (shifting to zero levels). This suggests that the DNA binding of the complex induces certain conformational changes, such as the conversion 


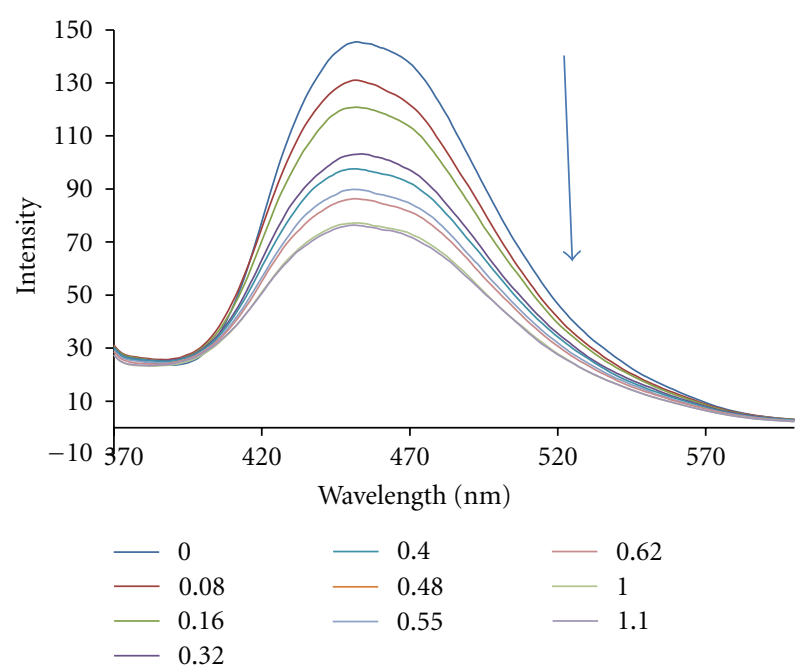

FIGURE 4

from a more B-like to a more C-like structure within the DNA molecule [47]. These changes are indicative of a nonintercalative mode of binding of the complex and offer support to its groove binding nature [48].

3.4. Fluorescence Spectroscopy. Quenching can occur by different mechanisms which are usually classified as dynamic and static quenching. Dynamic quenching refers to a process in which the fluorophore and the quencher come into contact during the transient existence of the exited state, while static quenching refers to fluorophore-quencher complex formation. In general, dynamic and static quenching can be distinguished by their differing dependence on temperature and excited-state lifetime. Since in both cases the fluorescence intensity is related to the concentration of the quencher, the quenched fluorophore can serve as an indicator for the quenching agent [49]. The effect of DNA on the fluorescence intensity of the complex is shown in Figure 4. Upon addition of CT-DNA, a decrease in emission intensity was observed for the complex. This implies that the title complex has a strong interaction with DNA. The quenching of the luminescence of the complex by CT-DNA may be attributed to the photoelectron transfer from the guanine bases of DNA to the excited MLCT state, as reported for other complexes [50,51].

Fluorescence quenching is described by the Stern-Volmer equation:

$$
\frac{F_{0}}{F}=1+K q \tau_{0}[\mathrm{Q}]=1+K_{\mathrm{sv}}[\mathrm{Q}]
$$

where $F_{0}$ and $F$ represent the fluorescence intensities in the absence and in the presence of quencher, respectively. $K q$ is the fluorophore quenching rate constant, $K_{\mathrm{sv}}$ is quenching constant, $\tau_{0}$ is the lifetime of the fluorophore in the absence of a quencher $\left(\tau_{0}=10^{-8}\right)$, and $[\mathrm{Q}]$ is the concentration of quencher [52]. Dynamic and static quenching can be distinguished by their different dependence on temperature [53]. The results in Table 1 indicate that the probable
TABLE 1: The quenching constants of the Fe(III) complex by CTDNA at different temperatures.

\begin{tabular}{lccc}
\hline Temperature $(K)$ & $R^{2}$ & $\begin{array}{c}K_{\mathrm{SV}} \\
\left(\mathrm{L} \mathrm{mol}^{-1}\right) \times 10^{4}\end{array}$ & $\begin{array}{c}K_{q} \\
\left(\mathrm{~L} \mathrm{~mol}^{-1}\right) \times 10^{12}\end{array}$ \\
\hline 288 & 0.992 & 7.046 & 7.046 \\
298 & 0.971 & 6.276 & 6.276 \\
310 & 0.921 & 2.683 & 2.683 \\
\hline
\end{tabular}

TABLe 2: Binding constants $\left(K_{f}\right)$ and the number of binding sites (n) of the complex DNA system.

\begin{tabular}{|c|c|c|c|c|c|}
\hline $\begin{array}{l}\text { Temperature } \\
(K)\end{array}$ & $\begin{array}{l}\text { Linear } \\
\text { equation }\end{array}$ & $R^{2}$ & $n$ & $K_{f}$ & $\log K_{f}$ \\
\hline 288 & $\begin{aligned} Y= & 1.678 X+ \\
& 8.176\end{aligned}$ & 0.990 & 1.678 & $1.49 \times 10^{8}$ & 8.176 \\
\hline 298 & $\begin{aligned} Y= & 0.644 X+ \\
& 4.549\end{aligned}$ & 0.987 & 0.644 & $3.54 \times 10^{4}$ & 4.549 \\
\hline 310 & $\begin{array}{c}Y=0.527 X+ \\
2.293\end{array}$ & 0.957 & 0.527 & $1.96 \times 10^{2}$ & 2.293 \\
\hline
\end{tabular}

quenching mechanism of this complex by CT-DNA involves static quenching, because $K_{\mathrm{sv}}$ decreases with increasing temperature [54].

3.4.1. Binding Constant and the Number of Binding Sites. The binding constant $\left(K_{f}\right)$ and the binding stoichiometry $(n)$ for the complex formation between iron complex and DNA were measured using (2) [55]

$$
\log \left(\frac{F_{0}-F}{F}\right)=\log K_{f}+n \log [Q] .
$$

Here, $F_{0}$ and $F$ are the fluorescence intensities of the fluorophore in the absence and presence of different concentrations of CT-DNA, respectively. The values of $K_{f}$ aaa and $n$ were found to be $3.54 \times 10^{4} \mathrm{M}^{-1}$ and 0.64 , respectively, (Table 2).

3.4.2. Binding Mode between the Complex and DNA. According to the thermodynamic data, interpreted as follows, the model of interaction between a drug and biomolecule can be [56]: (1) $\Delta H>0$ and $\Delta S>0$, hydrophobic forces; (2) $\Delta H<0$ and $\Delta S<0$, van der Waals interactions and hydrogen bonds; (3) $\Delta H<0$ and $\Delta S>0$, electrostatic interactions [57]. In order to elucidate the interaction of our complex with DNA, the thermodynamic parameters were calculated. The plot of $\ln K$ versus $1 / T$ (Figure 5; (3)) allows the determination of $\Delta H$ and $\Delta S$. If the temperature does not vary significantly, the enthalpy change can be regarded as a constant. Based on the binding constants at different temperatures, the free energy changes can be estimated (Table 3 ; (4)) by the following equations

$$
\begin{gathered}
\operatorname{Ln} K=-\frac{\Delta H}{R T}+\frac{\Delta S}{R}, \\
\Delta G=\Delta H-T \Delta S=-R T \operatorname{Ln} K,
\end{gathered}
$$

where $K$ is the Stern-Volmer quenching constant at the corresponding temperatures and $\mathrm{R}$ is the gas constant. When 
TABLE 3: Thermodynamic parameters and binding constants for the binding of $\mathrm{Fe}(\mathrm{III})$ complex to calf thymus DNA.

\begin{tabular}{lccc}
\hline Temperature $(K)$ & $\begin{array}{c}\Delta G \\
\left(\mathrm{KJ} \mathrm{mol}^{-1}\right)\end{array}$ & $\begin{array}{c}\Delta H \\
\left(\mathrm{KJ} \mathrm{mol}^{-1}\right)\end{array}$ & $\begin{array}{c}\Delta S \\
\left(\mathrm{~J} \mathrm{~mol}^{-1} \mathrm{~K}^{-1}\right)\end{array}$ \\
\hline 283 & -21.99 & -197.45 & -620.05 \\
299 & -12.07 & -197.45 & -620.05 \\
310 & -5.25 & -197.45 & -620.05 \\
\hline
\end{tabular}

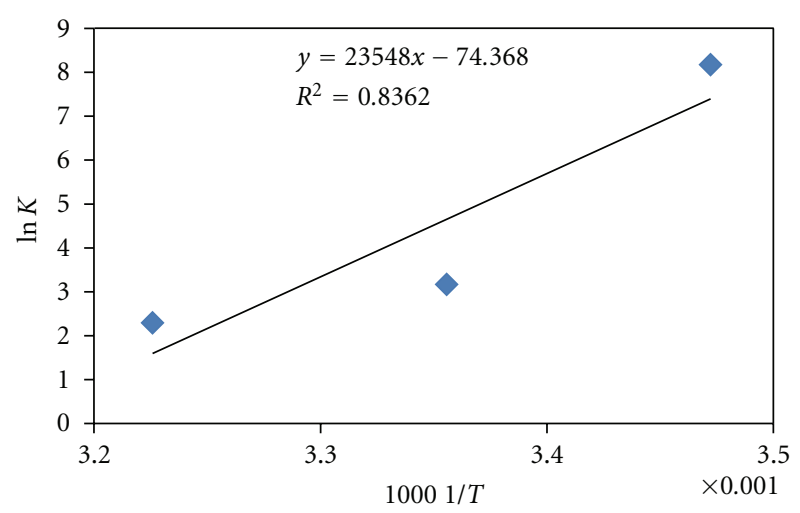

Figure 5

we apply this analysis to the binding of the complex with CTDNA, we find that $\Delta H<0$ and $\Delta S<0$. Therefore, van der Waals interactions or hydrogen bonds are probably the main forces in the binding of the titled complex to CT-DNA.

3.5. Absorption Studies. Electronic absorption spectroscopy was an effective method to examine the binding mode of DNA with metal complexes. In general, hypochromism and red shift are associated with the binding of the complex to the helix by an intercalative mode involving strong stacking interaction of the aromatic chromophore of the complex between the DNA base pairs. Figure 6 shows the UV-absorption spectra of the complex in the absence and presence of DNA. In the ultraviolet region from 200 to $400 \mathrm{~nm}$, the complex had strong absorption peaks at $260 \mathrm{~nm}$, besides a shoulder band around $340 \mathrm{~nm}$. The absorption intensity of the complex sample increased (hyperchromism; $\% \mathrm{H}=37.3 \%$ ) and no red shift evidently after the addition of DNA, which indicated the interactions between DNA and the complex. The hyperchromism of the complex, on addition of calf-thymus DNA, implies that the binding mode is non-intercalative in nature. This hyperchromism can be attributed to external contact (surface binding) with the duplex. Some similar hyperchromism have been observed [58-60]. But this needs further clarification of the DNA binding mode of the complex by viscosity measurements.

The absorption data were analyzed to evaluate the intrinsic binding constant, $K_{b}$, which can be determined from (5) [61],

$$
\frac{[\mathrm{DNA}]}{(\varepsilon a-\varepsilon f)}=\frac{[\mathrm{DNA}]}{(\varepsilon 0-\varepsilon f)}+\frac{1}{K_{b}(\varepsilon b-\varepsilon f)},
$$

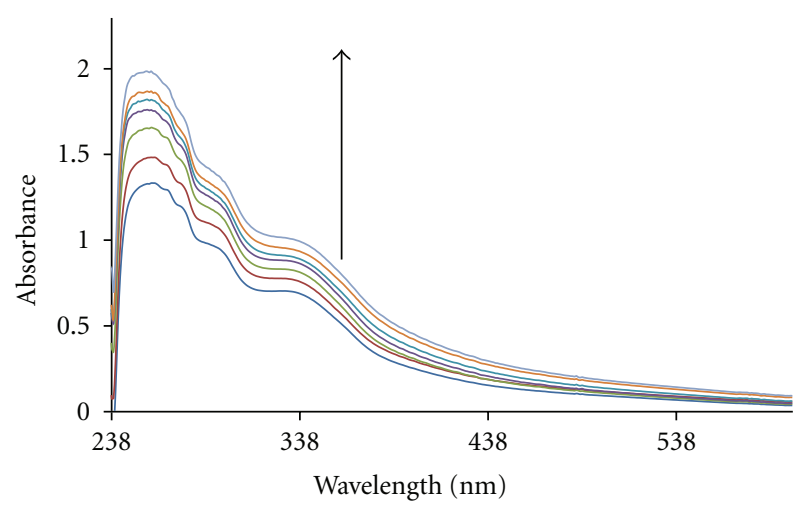

FIGURE 6

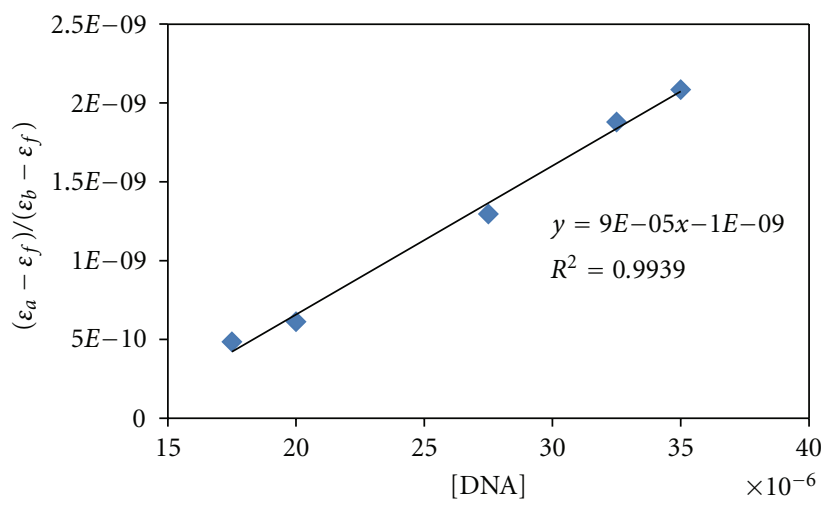

FIgURE 7

where [DNA] is the concentration of DNA in base pairs, the apparent absorption coefficient $\varepsilon a$, and $\varepsilon f$ and $\varepsilon b$ correspond to Aobsd/[M], the extinction coefficient of the free compound and the extinction coefficient of the compound when fully bound to DNA, respectively.

In plots of $[\mathrm{DNA}] /(\varepsilon a-\varepsilon f)$ versus $[\mathrm{DNA}], K_{b}$ is given by the ratio of slope to the intercept. The intrinsic bindingconstant, $K_{b}$, of complex was $9 \times 10^{4} \mathrm{M}^{-1}$ (Figure 7).

The $K_{b}$ value obtained here is lower than that reported for classical intercalators (for ethidium bromide and [Ru(phen)DPPZ] whose binding constants have been found to be in the order of $\left.10^{6}-10^{7} \mathrm{M}\right)[62,63]$. The observed binding constant is more in keeping with the groove binding with DNA, as observed in the literature [64].

The $K_{b}$ value for the complex is comparable to that observed for some complexes like, $\left[\mathrm{Co}(\text { phen })_{3}\right]^{3+}(1.6 \times$ $\left.10^{4} \mathrm{M}^{-1}\right)$ [65]; $\left.\left[\mathrm{Ru}(\text { phen })_{3}\right)^{2+}\right]\left(0.55 \times 10^{4} \mathrm{M}^{-1}\right)$ [66]; $\left(\mathrm{Ru} \quad(\text { phen })_{2}(\right.$ bpy $\left.)\right]\left(\mathrm{PF}_{6}\right)_{2} \quad\left(0.36 \times 10^{4} \mathrm{M}^{-1}\right) \quad[67] ; \quad[\mathrm{Ru}$ (phen) $\left.{ }_{2} \mathrm{~L}\right]^{+4}\left(2.5 \times 10^{4} \mathrm{M}^{-1}\right)$ [68] (electrostatic binding mode); $\left[\mathrm{Ru} \text { (tpy) }\left(\mathrm{pph}_{3}\right)_{2} \mathrm{Cl}\right]^{+}\left(K_{b}=4.1 \times 10^{4} \mathrm{M}^{-1}, s=\right.$ 0.34) [69]; [Ru (tpy) $\left.\left(\mathrm{Asph}_{3}\right) \mathrm{Cl}\right]^{+}\left(K_{b}=4.5 \times 10^{4} \mathrm{M}^{-1}, s=\right.$ 0.1) [69]; tricationic Co(III) complexes with asymmetric ligand, $\left[\mathrm{Co}(\text { phen })_{2}(\text { pdta })\right]^{3+}\left(K_{b}=2.8 \times 10^{4} \mathrm{M}^{-1}\right)[70]$; [Co $\left.(\text { bpy })_{2}(\mathrm{CNOIP})\right]^{3+}\left(K_{b}=5 \times 10^{4} \mathrm{M}^{-1}\right)[71]$. 


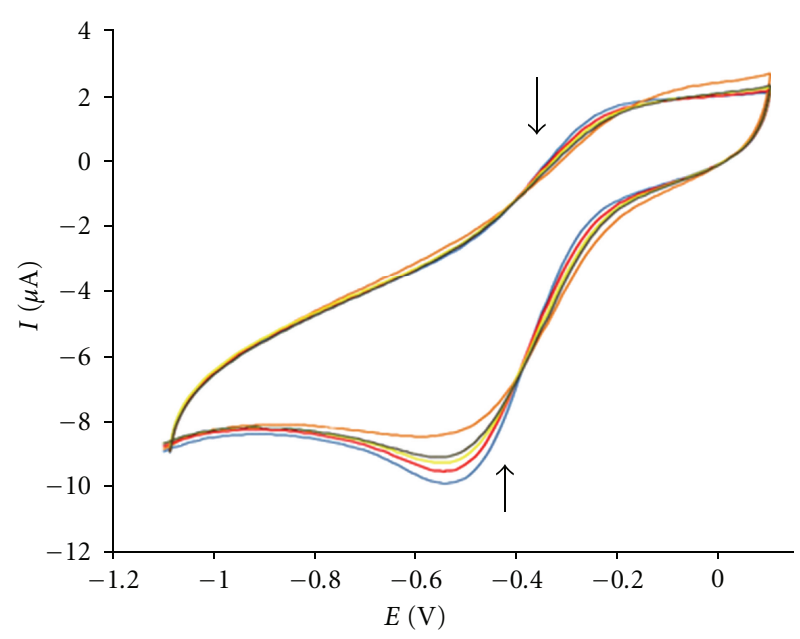

Figure 8

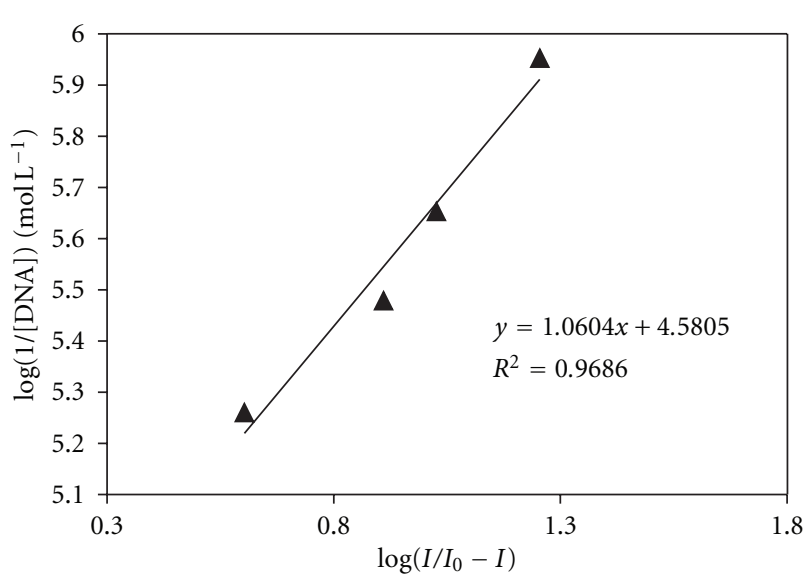

Figure 9: Cyclic voltammogram of $0.1 \mathrm{mM}$ Fe(III) complex on a polished glassy carbon electrode in the absence and presence of different concentrations of DNA. v: $100 \mathrm{mVs}^{-1}$, buffer: $0.05 \mathrm{M}$ Tris$\mathrm{HCl}$ buffer ( $\mathrm{pH} 7.4)$.

3.6. Voltammetric Studies. The application of electrochemical methods to the study of metallointercalation and coordination of transitional metal complexes to DNA provides a useful complement to the previously used methods of investigation, such as UV-vis spectroscopy [72, 73].

The electrochemical behavior of complex is well known, and was strongly influenced by the electrode material. A welldefined and sensitive peak was observed from the solution of the complex with a GC electrode rather than the Pt one. Therefore, a GC electrode was used in this investigation . When CT-DNA is added to a solution of the complex both the anodic and cathodic peak current heights of the complex decreased in the same manner of increasing additions of DNA, (Figure 8).

The substantial diminution in peak current is attributed to the formation of slowly diffusing complex-DNA supramolecular complex due to which the concentration of the free drug (mainly responsible for the transfer of current) is lowered [74].
The gradual decay in peak current of the complex by increasing of DNA concentration, ranging from 20$100 \mu \mathrm{M}$, can be used to quantify the binding constant by the application of the following equation [75]:

$$
\log \left(\frac{1}{[\mathrm{DNA}]}\right)=\log K+\log \left(\frac{I}{I_{0}-I}\right)
$$

where $K$ is the binding constant, $I_{0}$ and $I$ are the peak currents of the free guest and the complex, respectively.

The binding constant with a value of $3.81 \times 10^{4} \mathrm{~mol}^{-1} \mathrm{~L}$ was obtained from the intercept of $\log (1 /[\mathrm{DNA}])$ versus $\log \left(I /\left(I_{0}-I\right)\right)$ plot (Figure 9).

The values of binding constants obtained from UVvis absorption, fluorescence spectroscopy and CV measurements, $9 \times 10^{4}, 3.54 \times 10^{4}$ and $3.81 \times 10^{4} \mathrm{~mol}^{-1} \mathrm{~L}$, respectively, were in close agreement.

From the results of the above experiments, the formation of an electrochemically nonactive complex of the complex with DNA resulted in the decrease of the free concentration of the complex in the reaction solution, which caused the decrease of the peak current.

\section{Conclusion}

One of the most important goals of pharmacological research is the search for new molecular structures which exhibit effective antitumor activities. This has driven inorganic and organometallic chemists to look for new metal compounds with good activities, preferably against tumors that are responsible for high-cancer mortality. In this study, binding interaction of a water soluble iron(III) complex of a Schiff base, SF, (SF 1/4 N, $\mathrm{N}_{0}$-bis $\{5$-[ (triphenylphosphonium chloride)-methyl] salicylidene $\}$-o-phenylenediamine) with calf thymus DNA has been investigated and the results show that the complex can bind to DNA via groove binding mode.

\section{Acknowledgment}

The authors are grateful for the financial support of Razi University Research Center of Iran.

\section{References}

[1] A. A. A. Abu-Hussen, "Synthesis and spectroscopic studies on ternary bis-Schiff-base complexes having oxygen and/or nitrogen donors," Journal of Coordination Chemistry, vol. 59, no. 2, pp. 157-176, 2006.

[2] M. S. Karthikeyan, D. J. Prasad, B. Poojary, K. Subrahmanya Bhat, B. S. Holla, and N. S. Kumari, "Synthesis and biological activity of Schiff and Mannich bases bearing 2,4-dichloro5-fluorophenyl moiety," Bioorganic and Medicinal Chemistry, vol. 14, no. 22, pp. 7482-7489, 2006.

[3] K. Singh, M. S. Barwa, and P. Tyagi, "Synthesis, characterization and biological studies of $\mathrm{Co}$ (II), $\mathrm{Ni}$ (II), $\mathrm{Cu}$ (II) and $\mathrm{Zn}$ (II) complexes with bidentate Schiff bases derived by heterocyclic ketone," European Journal of Medicinal Chemistry, vol. 41, no. 1, pp. 147-153, 2006.

[4] P. Panneerselvam, R. R. Nair, G. Vijayalakshmi, E. H. Subramanian, and S. K. Sridhar, "Synthesis of Schiff bases of 4-(4aminophenyl)-morpholine as potential antimicrobial agents," 
European Journal of Medicinal Chemistry, vol. 40, no. 2, pp. 225-229, 2005.

[5] S. K. Sridhar, M. Saravanan, and A. Ramesh, "Synthesis and antibacterial screening of hydrazones, Schiff and Mannich bases of isatin derivatives," European Journal of Medicinal Chemistry, vol. 36, no. 7-8, pp. 615-625, 2001.

[6] S. N. Pandeya, D. Sriram, G. Nath, and E. Declercq, "Synthesis, antibacterial, antifungal and anti-HIV activities of Schiff and Mannich bases derived from isatin derivatives and $\mathrm{N}$-[4(4' -chlorophenyl)thiazol-2-yl] thiosemicarbazide," European Journal of Pharmaceutical Sciences, vol. 9, no. 1, pp. 25-31, 1999.

[7] R. Mladenova, M. Ignatova, N. Manolova, T. Petrova, and I. Rashkov, "Preparation, characterization and biological activity of Schiff base compounds derived from 8-hydroxyquinoline-2-carboxaldehyde and Jeffamines ED ${ }^{\circledR}$," European Polymer Journal, vol. 38, no. 5, pp. 989-999, 2002.

[8] O. M. Walsh, M. J. Meegan, R. M. Prendergast, and T. Al Nakib, "Synthesis of 3-acetoxyazetidin-2-ones and 3hydroxyazetidin-2-ones with antifungal and antibacterial activity," European Journal of Medicinal Chemistry, vol. 31, no. 12, pp. 989-1000, 1996.

[9] Z. Trávníček, M. Malo, Z. Šindelář et al., "Preparation, physicochemical properties and biological activity of copper(II) complexes with 6-(2-chlorobenzylamino)purine $\left(\mathrm{HL}_{1}\right)$ or 6(3-chlorobenzylamino)purine $\left(\mathrm{HL}_{2}\right)$. The single-crystal X-ray structure of $\left[\mathrm{Cu}\left(\mathrm{H}^{+} \mathrm{L}_{2}\right)_{2} \mathrm{Cl}_{3}\right] \mathrm{Cl} \cdot 2 \mathrm{H}_{2} \mathrm{O}$," Journal of Inorganic Biochemistry, vol. 84, no. 1-2, pp. 23-32, 2001.

[10] U. El-Ayaan and A. A. M. Abdel-Aziz, "Synthesis, antimicrobial activity and molecular modeling of cobalt and nickel complexes containing the bulky ligand: bis[N-(2,6diisopropylphenyl) imino] acenaphthene," European Journal of Medicinal Chemistry, vol. 40, no. 12, pp. 1214-1221, 2005.

[11] M. Sönmez, I. Berber, and E. Akbaş, "Synthesis, antibacterial and antifungal activity of some new pyridazinone metal complexes," European Journal of Medicinal Chemistry, vol. 41, no. 1, pp. 101-105, 2006.

[12] E. Keskioğlu, A. B. Gündüzalp, S. Çete, F. Hamurcu, and B. Erk, "Cr(III), $\mathrm{Fe}(\mathrm{III})$ and $\mathrm{Co}(\mathrm{III})$ complexes of tetradentate (ONNO) Schiff base ligands: synthesis, characterization, properties and biological activity," Spectrochimica Acta-Part A, vol. 70, no. 3, pp. 634-640, 2008.

[13] J.-Z. Wu and L. Yuan, "Synthesis and DNA interaction studies of a binuclear ruthenium(II) complex with 2,9-bis(2imidazo $[4,5-f][1,10]$ phenanthroline)-1,10-phenanthroline as bridging and intercalating ligand," Journal of Inorganic Biochemistry, vol. 98, no. 1, pp. 41-45, 2004.

[14] K. P. Balasubramanian, K. Parameswari, V. Chinnusamy, R. Prabhakaran, and K. Natarajan, "Synthesis, characterization, electro chemistry, catalytic and biological activities of ruthenium(III) complexes with bidentate N, O/S donor ligands," Spectrochimica Acta-Part A, vol. 65, no. 3-4, pp. 678-683, 2006.

[15] S. Yamada, "Advancement in stereochemical aspects of Schiff base metal complexes," Coordination Chemistry Reviews, vol. 190-192, pp. 537-555, 1999.

[16] A. Böttcher, T. Takeuchi, K. I. Hardcastle et al., "Spectroscopy and electrochemistry of cobalt(III) schiff base complexes," Inorganic Chemistry, vol. 36, no. 12, pp. 2498-2504, 1997.

[17] E. Canpolat and M. Kaya, "Studies on mononuclear chelates derived from substituted Schiff-base ligands (part 2): synthesis and characterization of a new 5-bromosalicyliden- $p$ aminoacetophenoneoxime and its complexes with $\mathrm{Co}(\mathrm{II})$,
$\mathrm{Ni}(\mathrm{II}), \mathrm{Cu}(\mathrm{II})$ and $\mathrm{Zn}(\mathrm{II})$," Journal of Coordination Chemistry, vol. 57, no. 14, pp. 1217-1223, 2004.

[18] R. L. Lucas, M. K. Zart, J. Murkerjee, T. N. Sorrell, D. R. Powell, and A. S. Borovik, "A modular approach toward regulating the secondary coordination sphere of metal ions: differential dioxygen activation assisted by intramolecular hydrogen bonds," Journal of the American Chemical Society, vol. 128, no. 48, pp. 15476-15489, 2006.

[19] P. E. Aranha, M. P. dos Santos, S. Romera, and E. R. Dockal, "Synthesis, characterization, and spectroscopic studies of tetradentate Schiff base chromium(III) complexes," Polyhedron, vol. 26, no. 7, pp. 1373-1382, 2007.

[20] A. A. Soliman and W. Linert, "Structural features of ONSdonor salicylidene Schiff base complexes," Monatshefte fur Chemie, vol. 138, no. 3, pp. 175-189, 2007.

[21] M. Xie, G. Xu, L. Li, W. Liu, Y. Niu, and S. Yan, "In vivo insulin-mimetic activity of [N,N-1,3-propyl-bis(salicyladimine)] oxovanadium(IV)," European Journal of Medicinal Chemistry, vol. 42, no. 6, pp. 817-822, 2007.

[22] V. Milacic, D. Chen, L. Ronconi, K. R. Landis-Piwowar, D. Fregona, and Q. P. Dou, "A novel anticancer gold(III) dithiocarbamate compound inhibits the activity of a purified $20 \mathrm{~S}$ proteasome and $26 \mathrm{~S}$ proteasome in human breast cancer cell cultures and xenografts," Cancer Research, vol. 66, no. 21, pp. 10478-10486, 2006.

[23] I. Kostova, "Gold coordination complexes as anticancer agents," Anti-Cancer Agents in Medicinal Chemistry, vol. 6, no. 1, pp. 19-32, 2006.

[24] F. Li, W. Chen, C. Tang, and S. Zhang, "Recent development of interaction of transition metal complexes with DNA based on biosensor and its applications," Talanta, vol. 77, no. 1, pp. $1-8,2008$.

[25] R. A. Sanchez-Delgado, A. Anzellotti, and L. Suarez, "Metal complexes as chemotherapeutic agents against tropical diseases: malaria, leishmaniasis and trypanosomiasis," in Metal Ions in Biological Systems, H. Sigel and A. Sigel, Eds., pp. 379419, Marcel Dekker, New York, Ny, USA, 2004.

[26] I. Bertini, H. B. Gray, and E. I. Stiefel, Biological Inorganic Chemistry: Structure and Reactivity, University Science Books, Sausalito, Calif, USA, 2007.

[27] R. R. Tidwell and D. W. Boykin, "Dicationic DNA minor groove binders as antimicrobial agents," in DNA and RNA Binders From Small Molecules to Drags, M. Demeunynck, C. Bailly, and W. D. Wilson, Eds., Wiley-VCH, 2003.

[28] A. K. Patra, M. Nethaji, and A. R. Chakravarty, "Synthesis, crystal structure, DNA binding and photo-induced DNA cleavage activity of ( $S$-methyl- ${ }_{L}$-cysteine) copper(II) complexes of heterocyclic bases," Journal of Inorganic Biochemistry, vol. 101, no. 2, pp. 233-244, 2007.

[29] A. K. Patra, T. Bhowmick, S. Roy, S. Ramakumar, and A. R. Chakravarty, "Copper(II) complexes of L-arginine as netropsin mimics showing DNA cleavage activity in red light," Inorganic Chemistry, vol. 48, no. 7, pp. 2932-2943, 2009.

[30] S. Ramakrishnan, V. Rajendiran, M. Palaniandavar et al., "Induction of cell death by ternary copper(II) complexes of 1tyrosine and diimines: role of coligands on DNA binding and cleavage and anticancer activity," Inorganic Chemistry, vol. 48, no. 4, pp. 1309-1322, 2009.

[31] D. B. Hall, R. E. Holmlin, and J. K. Barton, "Oxidative DNA damage through long-range electron transfer," Nature, vol. 382, no. 6593, pp. 731-735, 1996.

[32] K. E. Erkkila, D. T. Odom, and J. K. Barton, "Recognition and reaction of metallointercalators with DNA," Chemical Reviews, vol. 99, no. 9, pp. 2777-2795, 1999. 
[33] B. Lippert, "Multiplicity of metal ion binding patterns to nucleobases," Coordination Chemistry Reviews, vol. 200-202, pp. 487-516, 2000.

[34] C. Liu, M. Wang, T. Zhang, and H. Sun, "DNA hydrolysis promoted by di- and multi-nuclear metal complexes," Coordination Chemistry Reviews, vol. 248, no. 1-2, pp. 147-168, 2004.

[35] G. Pratviel, J. Bernadou, and B. Meunier, "DNA and RNA cleavage by metal complexes," Advances in Inorganic Chemistry, vol. 45, pp. 251-312, 1998.

[36] M. Shionoya, T. Ikeda, E. Kimura, and M. Shiro, "Novel "multipoint" molecular recognition of nucleobases by a new zinc(II) complex of acridine-pendant cyclen (cyclen = 1,4,7,10tetraazacyclododecane)," Journal of the American Chemical Society, vol. 116, no. 9, pp. 3848-3859, 1994.

[37] D. M. Epstein, L. L. Chappell, H. Khalili, R. M. Supkowski, W. W. De Horrocks, and J. R. Morrow, "Eu(III) macrocyclic complexes promote cleavage of and bind to models for the $5^{\prime}$ cap of mRNA. Effect of pendent group and a second metal ion," Inorganic Chemistry, vol. 39, no. 10, pp. 2130-2134, 2000.

[38] X.-Y. Wang, J. Zhang, K. Li et al., "Synthesis and DNA cleavage activities of mononuclear macrocyclic polyamine zinc(II), copper(II), cobalt(II) complexes which linked with uracil," Bioorganic and Medicinal Chemistry, vol. 14, no. 19, pp. 67456751, 2006.

[39] X. B. Yang, J. Feng, J. Zhang et al., "Synthesis, DNA binding and cleavage activities of the copper (II) complexes of estrogen-macrocyclic polyamine conjugates," Bioorganic and Medicinal Chemistry, vol. 16, no. 7, pp. 3871-3877, 2008.

[40] R. Ramesh and M. Sivagamasundari, "Synthesis, spectral, and antifungal activity of Ru(II) mixed-ligand complexes," Synthesis and Reactivity in Inorganic and Metal-Organic Chemistry, vol. 33, no. 5, pp. 899-910, 2003.

[41] N. Deligönül, M. Tümer, and S. Serin, "Synthesis, characterization, catalytic, electrochemical and thermal properties of tetradentate Schiff base complexes," Transition Metal Chemistry, vol. 31, no. 7, pp. 920-929, 2006.

[42] N. Shahabadi, S. Kashanian, and F. Darabi, "In Vitro study of DNA interaction with a water-soluble dinitrogen schiff base," DNA and Cell Biology, vol. 28, no. 11, pp. 589-596, 2009.

[43] B. A. Uzoukwu, K. Gloe, and H. Duddeck, "4-acylpyrazoloneiminjz Schiff bases and their metal complexes: synthesis and spectroscopic studies," Synthesis and Reactivity in Inorganic and Metal-Organic Chemistry, vol. 28, no. 5, pp. 819-831, 1998.

[44] J. M. Kelly, A. B. Tossi, D. J. Mcconnell, and C. Ohuigin, "A study of the interactions of some polypyridylruthenium(II) complexes with DNA using fluorescence spectroscopy, topoisomerisation and thermal denaturation," Nucleic Acids Research, vol. 13, no. 17, pp. 6017-6034, 1985.

[45] G. L. Eichhorn and Y. A. Shin, "Interaction of metal ions with polynucleotides and related compounds. XII. The relative effect of various metal ions on DNA helicity," Journal of the American Chemical Society, vol. 90, no. 26, pp. 7323-7328, 1968.

[46] N. Shahabadi, S. Kashanian, M. Khosravi, and M. Mahdavi, "Multispectroscopic DNA interaction studies of a watersoluble nickel(II) complex containing different dinitrogen aromatic ligands," Transition Metal Chemistry, vol. 35, no. 6, pp. 699-705, 2010.

[47] S. Mahadevan and M. Palaniandavar, "Spectroscopic and voltammetric studies on copper complexes of 2,9-dimethyl1,10-phenanthrolines bound to calf thymus DNA," Inorganic Chemistry, vol. 37, no. 4, pp. 693-700, 1998.
[48] P. Uma Maheswari and M. Palaniandavar, "DNA binding and cleavage properties of certain tetrammine ruthenium(II) complexes of modified 1,10-phenanthrolines - effect of hydrogenbonding on DNA-binding affinity," Journal of Inorganic Biochemistry, vol. 98, no. 2, pp. 219-230, 2004.

[49] M. R. Eftink and C. A. Ghiron, "Fluorescence quenching studies with proteins," Analytical Biochemistry, vol. 114, no. 2, pp. 199-227, 1981.

[50] B. Peng, H. Chao, B. Sun, H. Li, F. Gao, and L.-N. Ji, "Synthesis, DNA-binding and photocleavage studies of cobalt(III) mixed-polypyridyl complexes: $\left[\mathrm{Co}(\text { phen })_{2}(\mathrm{dpta})\right]^{3+}$ and $\left[\mathrm{Co}(\mathrm{phen})_{2}(\mathrm{amtp})\right]^{3+}$, , Journal of Inorganic Biochemistry, vol. 101, no. 3, pp. 404-411, 2007.

[51] V. G. Vaidyanathan and B. U. Nair, "Photooxidation of DNA by a cobalt(II) tridentate complex," Journal of Inorganic Biochemistry, vol. 94, no. 1-2, pp. 121-126, 2003.

[52] Y. Sun, S. Bi, D. Song, C. Qiao, D. Mu, and H. Zhang, "Study on the interaction mechanism between DNA and the main active components in Scutellaria baicalensis Georgi," Sensors and Actuators, B, vol. 129, no. 2, pp. 799-810, 2008.

[53] F.-L. Cui, J. Fan, J.-P. Li, and Z.-D. Hu, "Interactions between 1-benzoyl-4-p-chlorophenyl thiosemicarbazide and serum albumin: investigation by fluorescence spectroscopy," Bioorganic and Medicinal Chemistry, vol. 12, no. 1, pp. 151157, 2004.

[54] P. B. Kandagal, S. M. T. Shaikh, D. H. Manjunatha, J. Seetharamappa, and B. S. Nagaralli, "Spectroscopic studies on the binding of bioactive phenothiazine compounds to human serum albumin," Journal of Photochemistry and Photobiology A, vol. 189, no. 1, pp. 121-127, 2007.

[55] M. Jiang, M.-X. Xie, D. Zheng, Y. Liu, X.-Y. Li, and X. Chen, "Spectroscopic studies on the interaction of cinnamic acid and its hydroxyl derivatives with human serum albumin," Journal of Molecular Structure, vol. 692, no. 1-3, pp. 71-80, 2004.

[56] M. Jiang, M.-X. Xie, D. Zheng, Y. Liu, X.-Y. Li, and X. Chen, "Spectroscopic studies on the interaction of cinnamic acid and its hydroxyl derivatives with human serum albumin," Journal of Molecular Structure, vol. 692, no. 1-3, pp. 71-80, 2004.

[57] N. Shahabadi and A. Fatahi, "Multispectroscopic DNAbinding studies of a tris-chelate nickel(II) complex containing 4,7-diphenyl 1,10-phenanthroline ligands," Journal of Molecular Structure, vol. 970, no. 1-3, pp. 90-95, 2010.

[58] R. F. Pasternack, E. J. Gibbs, and J. J. Villafranca, "Interactions of porphyrins with nucleic acids," Biochemistry, vol. 22, no. 10, pp. 2406-2414, 1983.

[59] S. Mahadevan and M. Palaniandavar, "Spectroscopic and voltammetric studies on copper complexes of 2,9-dimethyl1,10-phenanthrolines bound to calf thymus DNA," Inorganic Chemistry, vol. 37, no. 4, pp. 693-700, 1998.

[60] S. Kashanian, M. B. Gholivand, F. Ahmadi, A. Taravati, and A. H. Colagar, "DNA interaction with Al-N,N-bis (salicylidene) 2,2' - phenylendiamine complex," Spectrochimica Acta-Part A, vol. 67, no. 2, pp. 472-478, 2007.

[61] A. Wolfe, G. H. Shimer Jr., and T. Meehan, "Polycyclic aromatic hydrocarbons physically intercalate into duplex regions of denatured DNA," Biochemistry, vol. 26, no. 20, pp. 6392-6396, 1987.

[62] M. Cory, D. D. McKee, J. Kagan, D. W. Henry, and J. A. Miller, "Design, synthesis, and DNA binding properties of bifunctional intercalators. Comparison of polymethylene and diphenyl ether chains connecting phenanthridine," Journal of the American Chemical Society, vol. 107, no. 8, pp. 2528-2536, 1985. 
[63] M. J. Waring, "Complex formation between ethidium bromide and nucleic acids," Journal of Molecular Biology, vol. 13, no. 1, pp. 269-282, 1965.

[64] V. G. Vaidyanathan and B. U. Nair, "Photooxidation of DNA by a cobalt(II) tridentate complex," Journal of Inorganic Biochemistry, vol. 94, no. 1-2, pp. 121-126, 2003.

[65] S. Arounaguiri, D. Easwaramoorthy, A. Ashokkumar, A. Dattagupta, and B. G. Maiya, "Cobalt(III), nickel(II) and ruthenium(II) complexes of 1,10-phenanthroline family of ligands: DNA binding and photocleavage studies," Proceedings of the Indian Academy of Sciences: Chemical Sciences, vol. 112, no. 1, pp. 1-17, 2000.

[66] T.-R. Li, Z.-Y. Yang, B.-D. Wang, and D.-D. Qin, "Synthesis, characterization, antioxidant activity and DNA-binding studies of two rare earth(III) complexes with naringenin2-hydroxy benzoyl hydrazone ligand," European Journal of Medicinal Chemistry, vol. 43, no. 8, pp. 1688-1695, 2008.

[67] P. Uma Maheswari, V. Rajendiran, M. Palaniandavar, R. Thomas, and G. U. Kulkarni, "Mixed ligand ruthenium(II) complexes of 5,6-dimethyl-1,10-phenanthroline: the role of ligand hydrophobicity on DNA binding of the complexes," Inorganica Chimica Acta, vol. 359, no. 14, pp. 4601-4612, 2006.

[68] J. Sun, S. Wu, Y. An et al., "Synthesis, crystal structure and DNA-binding properties of ruthenium(II) polypyridyl complexes with dicationic 2,2' -dipyridyl derivatives as ligands," Polyhedron, vol. 27, no. 13, pp. 2845-2850, 2008.

[69] S. Sharma, S. K. Singh, M. Chandra, and D. S. Pandey, "DNAbinding behavior of ruthenium(II) complexes containing both group 15 donors and 2,2':6',2' -terpyridine," Journal of Inorganic Biochemistry, vol. 99, no. 2, pp. 458-466, 2005.

[70] X.-L. Wang, H. Chao, H. Li et al., "DNA interactions of cobalt(III) mixed-polypyridyl complexes containing asymmetric ligands," Journal of Inorganic Biochemistry, vol. 98, no. 6, pp. 1143-1150, 2004.

[71] Q.-L. Zhang, J.-G. Liu, J. Liu et al., "DNA-binding and photocleavage studies of cobalt(III) mixed-polypyridyl complexes containing 2-(2-chloro-5-nitrophenyl)imidazo [4,5$f][1,10]$ phenanthroline," Journal of Inorganic Biochemistry, vol. 85, no. 4, pp. 291-296, 2001.

[72] D. H. Johnston, K. C. Glasgow, and H. H. Thorp, "Electrochemical measurement of the solvent accessibility of nucleobases using electron transfer between DNA and metal complexes," Journal of the American Chemical Society, vol. 117, no. 35, pp. 8933-8938, 1995.

[73] R. Indumathy, S. Radhika, M. Kanthimathi, T. Weyhermuller, and B. Unni Nair, "Cobalt complexes of terpyridine ligand: crystal structure and photocleavage of DNA," Journal of Inorganic Biochemistry, vol. 101, no. 3, pp. 434-443, 2007.

[74] Y. M. Song, Q. Wu, P. J. Yang, N. N. Luan, L. F. Wang, and Y. M. Liu, "DNA Binding and cleavage activity of Ni(II) complex with all-trans retinoic acid," Journal of Inorganic Biochemistry, vol. 100, no. 10, pp. 1685-1691, 2006.

[75] Q. Feng, N.-Q. Li, and Y.-Y. Jiang, "Electrochemical studies of porphyrin interacting with DNA and determination of DNA," Analytica Chimica Acta, vol. 344, no. 1-2, pp. 97-104, 1997. 


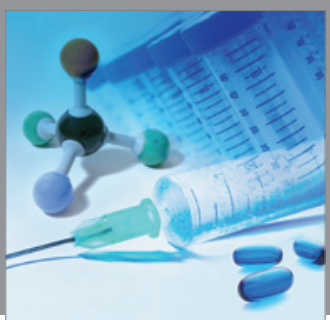

International Journal of

Medicinal Chemistry

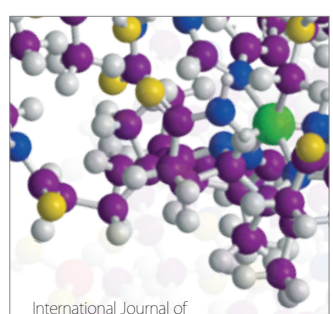

Carbohydrate Chemistry

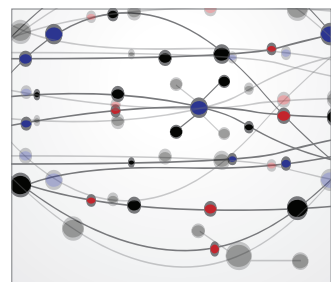

The Scientific World Journal
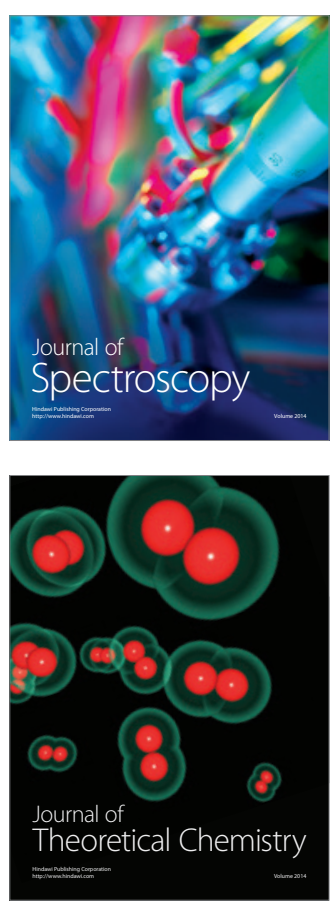
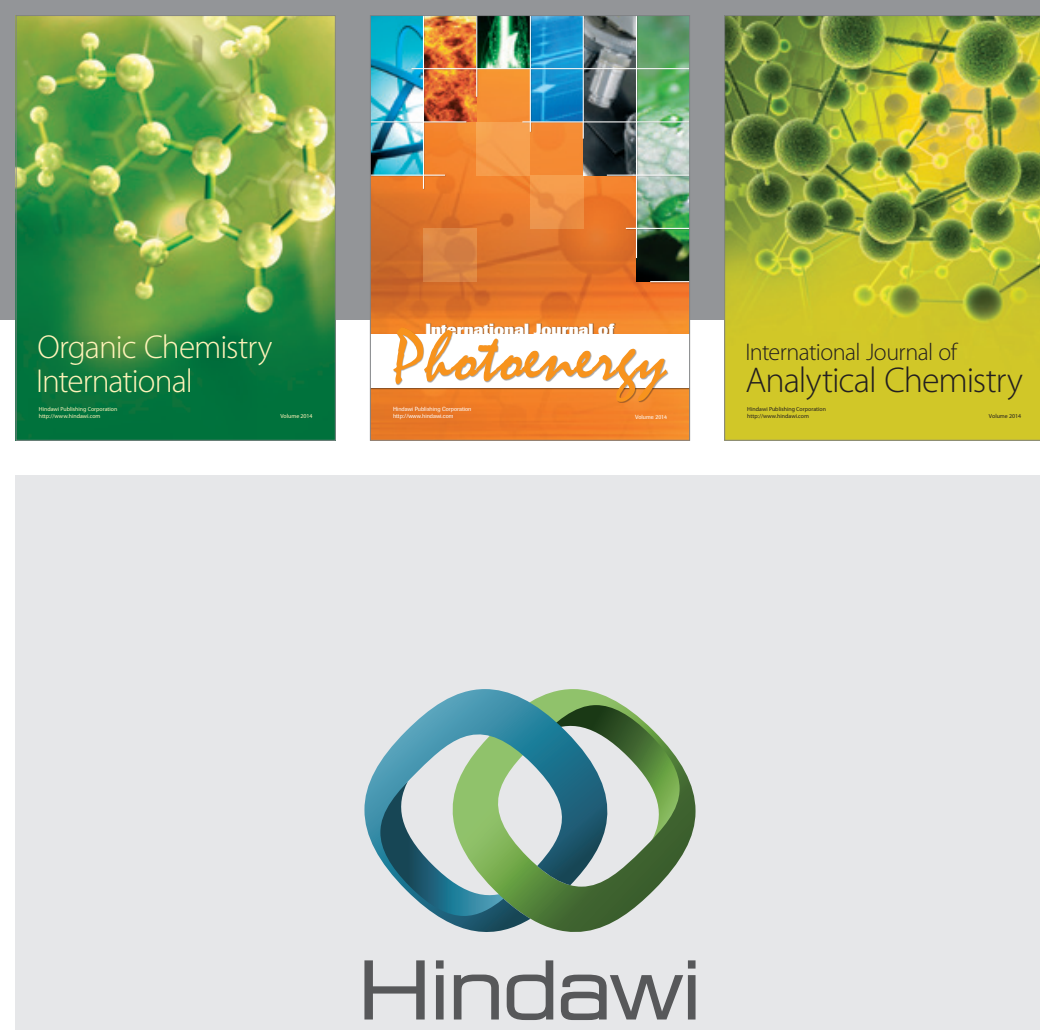

Submit your manuscripts at

http://www.hindawi.com
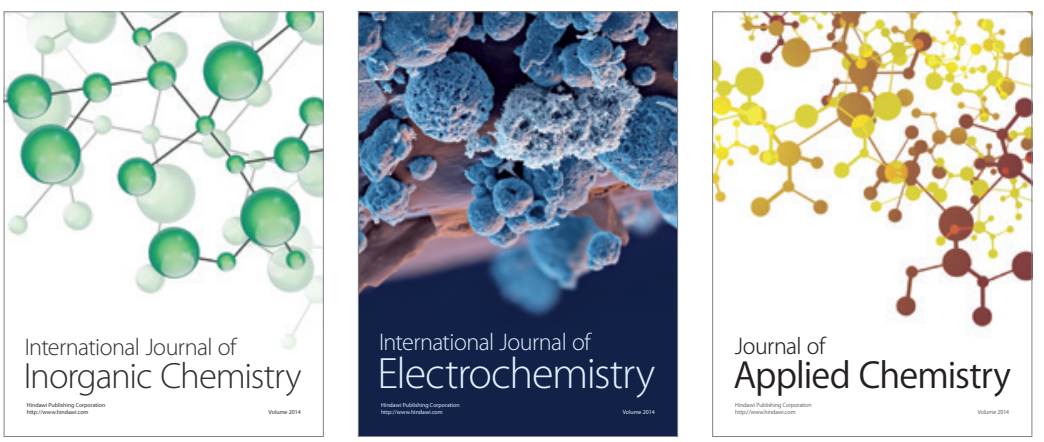

Journal of

Applied Chemistry
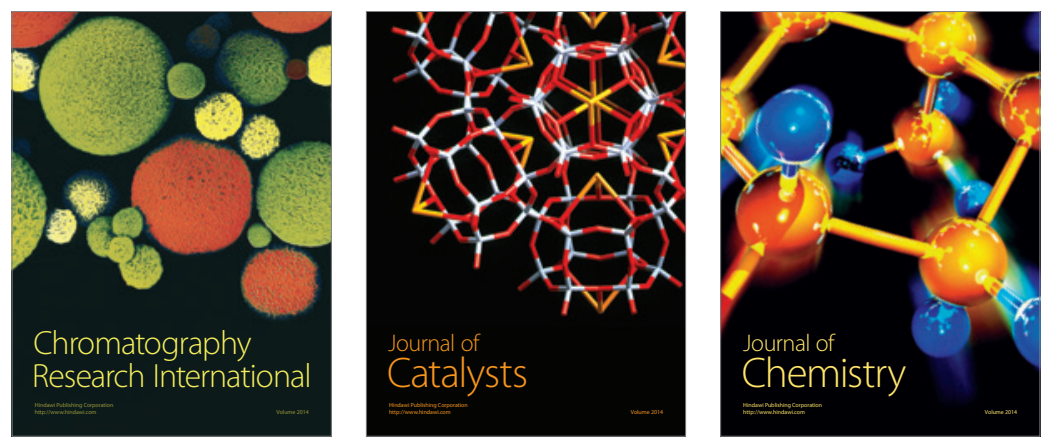
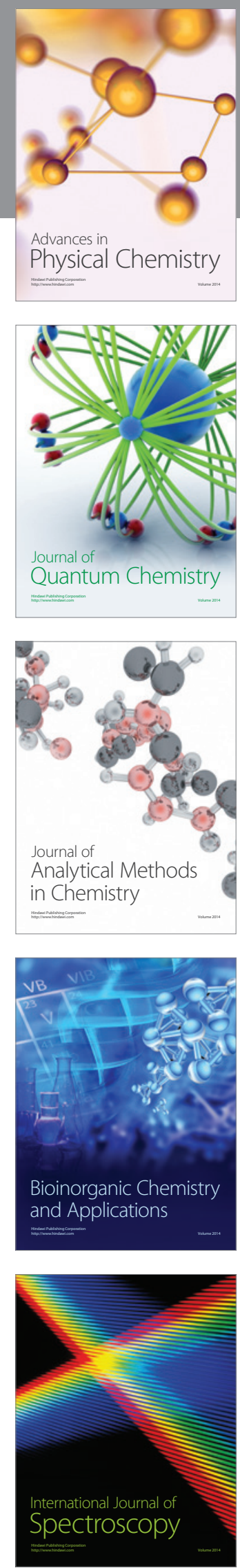